\title{
KONTRIBUSI KUALITAS LAYANAN TERHADAP KEPUASAN SERTA DAMPAKNYA PADA LOYALITAS PELANGGAN
}

\author{
Cecep Hidayat ${ }^{1}$; Putri Melinda ${ }^{2}$ \\ 1,2 Jurusan Manajemen, Fakultas Ekonomi dan Bisnis, Universitas Bina Nusantara, \\ Jln. K.H. Syahdan No. 9, Palmerah, Jakarta Barat 11480 \\ ceceph1267@binus.ac.id
}

\begin{abstract}
The purpose of this research is to find contribution of service quality towards building customer satisfaction, and the contribution of service quality towards customer loyalty, and the contribution of both service quality and customer satisfaction towards customer loyalty simultaneously, and find out whether there is any contribution of customer satisfaction to customer loyalty. The type of research used is associative survey and the analysis technique used is path analysis. The data are obtained through a survey with questionaire as the main instrument. This questionnaire is distributed to customers of Indosat BlackBerry ISATBB community. Results showed that there are positive and significant contributions of service quality towards customer satisfaction, customer satisfaction to customer loyalty, and service quality to customer loyalty all directly or indirectly.
\end{abstract}

Keywords: service quality, consumer satisfaction, consumer loyalty

\begin{abstract}
ABSTRAK
Tujuan dari penelitian ini adalah untuk mengetahui kontribusi kualitas pelayanan terhadap membangun kepuasan pelanggan, dan kontribusi kualitas pelayanan terhadap loyalitas pelanggan, dan kontribusi baik kualitas pelayanan dan kepuasan pelanggan terhadap loyalitas pelanggan secara simultan, dan mencari tahu apakah ada kontribusi apapun kepuasan pelanggan terhadap loyalitas pelanggan. Jenis penelitian yang digunakan adalah survei asosiatif dan teknik analisis yang digunakan adalah analisis jalur. Data diperoleh melalui survei dengan kuesioner sebagai instrumen utama. Kuesioner ini didistribusikan kepada pelanggan dalam komunitas Indosat BlackBerry ISATBB. Hasil penelitian menunjukkan bahwa ada kontribusi positif dan signifikan dari kualitas pelayanan terhadap kepuasan pelanggan, kepuasan pelanggan terhadap loyalitas pelanggan, kualitas pelayanan terhadap loyalitas pelanggan semua secara langsung ataupun tidak langsung
\end{abstract}

Kata kunci: kualitas pelayanan, Kepuasan konsumen, loyalitas konsumen 


\section{PENDAHULUAN}

Teknologi selular dewasa ini telah banyak mengalami perkembangan, jenis yang banyak berkembang saat ini adalah "Smart Phone" dimana ponsel didukung oleh fitur yang mendukung dan mempermudah penggunanya dalam berkomunikasi. Sebagai contoh Research In Motion (RIM) perusahaan asal Kanada ini yang memperkenalkan BlackBerry untuk pertama kalinya pada tahun 1997 dengan kemampuannya menyampaikan informasi melalui jaringan data nirkabel dan layanan perusahaan telepon genggam mengejutkan dunia. Pada tahun 2008 BlackBerry telah menyumbangkan angka penjualan terbesar bagi RIM di Asia.

BlackBerry pertama kali di perkenalkan di Indonesia pada 15 Desember 2004 oleh Indosat. Setiap tahun penjualan BlackBerry di Indonesia semakin meningkat. Sayangnya peningkatan angka penjualan BlackBerry di Indonesia tidak didukung oleh Research In Motion (RIM) untuk membuka kantor cabang atau service center resmi di Indonesia untuk mempermudah layanan konsumennya. Tetapi menurut pengakuan RIM, mereka telah membekali karyawan di operator telekomunikasi yang bekerja sama dengannya dengan kemampuan memperbaiki setiap keluhan yang mungkin terjadi dengan ponsel pintar pelanggan. Kelebihan handset BlackBerry ini dibandingkan dengan smartphone lainnya adalah koneksi GPRS yang selalu aktif untuk push-email namun battery tetap tahan lama. Kemudian kelebihan BlackBerry lainnya adalah data compression technique pada setiap email.

Kelebihan lainnya adalah data loss prevention, dimana apabila handset didiamkan tanpa battery selama beberapa minggu kemudian dihidupkan kembali, maka semua data yang ada masih tetap tersimpan. Masalah keamanan juga membuat BlackBerry lebih unggul dibanding dengan smartphone lainnya dengan mode encryption 128bit sehingga kemungkinan data disadap juga menjadi lebih kecil. Selain itu aplikasi BlackBerry harus di signed oleh RIM sehingga membuat BlackBerry aman dari virus, spyware dan sebagainya. Pertama kali, bundling merupakan strategi penjualan BlackBerry yang di lakukan oleh RIM untuk dapat memenuhi kebutuhan konsumennya di Indonesia. Research In Motion bekerja sama dengan operator telekomunikasi untuk menjual produknya BlackBerry bersama atau satu paket dengan layanan BlackBerry yang ditawarkan oleh operator tertentu. Paket bundling dapat diartikan bahwa operator menjual headset BlackBerry dengan sistem kunci (lock) yang artinya jika menggunakan kartu dari operator lain pada headset tersebut, BlackBerry tersebut tidak akan mengenalinya sebagai kartu UIM/SIM alias tidak berfungsi. Keuntungan dari membeli bundling BlackBerry dari operator adalah mendapatkan paket-paket menguntungkan dan mendapatkan garansi resmi dari operator tersebut yang tidak didapatkan apabila membeli BlackBerry melalui distributor toko. Namun seiring persaingan yang semakin ketat dan permintaan para pengguna layanan BlackBerry, Indosat mempersilahkan para pengguna BlackBerry resminya untuk membuka kunci (meng-unlock) headset mereka.

Indosat sebagai operator pertama yang menjual headset BlackBerry resmi bekerja sama dengan Research In Motion dan penyedia layanan BlackBerry Internet Service dan BlackBerry Enterprise Server di Indonesia harus menyiapkan strategi agar dapat bersaing dengan perusahaan operator pesaingnya yang menyediakan layanan Blackberry Internet Services (BIS) dan Blackberry Enterprise Solution (BES) seperti PT. XL Axiata dan Telkomsel. Tarif layanan BlackBerry Indosat sekarang sangatlah kompetitif dengan pesaing. Indosat selalu mempunyai inovasi - inovasi layanan BlackBerry, berbagai segmen pun di ambil, mulai dari segmen profesional sampai segmen anak muda. Tarif layanan untuk masing-masing segmen pun berbeda-beda. Perbedaan tarif layanan tidak mengurangi kualitas yang di dapatkan oleh pelanggan. Dengan adanya kualitas yang baik dari layanan BlackBerry Indosat akan berdampak pada peningkatan tingkat kepuasan pelanggan terhadap layanan tersebut. Berikut adalah jumlah keluhan pelanggan layanan BlackBerry Indosat diperoleh melalui milis ISATBB. 
Pelanggan yang sangat puas akan cenderung tetap setia dalam waktu yang lebih lama, membeli lebih banyak ketika perusahaan memperkenalkan produk baru dan memperbarui produkproduk yang ada, membicarakan hal-hal yang baik tentang perusahaan dan produknya, memberi perhatian yang lebih sedikit pada merek dan iklan para pesaing serta kurang peka terhadap harga, menawarkan gagasan tentang jasa atau produk kepada perusahaan, dan membutuhkan biaya pelayanan yang lebih kecil dibandingkan biaya pelayanan pelanggan baru karena transaksinya rutin. Berdasarkan uraian yang telah dikemukakan, penulis tertarik untuk melakukan penilitian sejauh mana pengaruh kualitas layanan terhadap kepuasan pelanggan dan dampaknya pada loyalitas pelanggan tersebut.

Berdasarkan latar belakang masalah yang telah dikemukakan diatas, maka diambil beberapa identifikasi masalah sebagai berikut: Adakah kontribusi yang signifikan antara Kualitas Layanan terhadap Kepuasan Pelanggan layanan BlackBerry Indosat? Adakah kontribusi yang signifikan antara Kualitas Layanan terhadap Loyalitas Pelanggan layanan BlackBerry Indosat? Adakah kontribusi yang signifikan antara Kualitas Layanan dan Kepuasan Pelanggan dan secara simultan terhadap Loyalitas Pelanggan layanan BlackBerry Indosat? Apakah ada kontribusi yang signifikan antara Kepuasan Pelanggan terhadap Loyalitas Pelanggan layanan BlackBerry Indosat?

\section{METODE PENELITIAN}

\section{Jenis dan Sumber Data Penelitian}

Jenis penelitian yang digunakan adalah asosiatif dan metode penelitian yang digunakan adalah survey dengan menggunakan kuesioner sebagai instrumen utama dalam pengumpulan data. Sumber data utama adalah data primer yang berasal dari jawaban 100 responden nasabah Bank Sinarmas yang terpilih sebagai responden.

\section{Populasi dan Sampling}

Populasi dalam penelitian ini adalah pelanggan Blackberry Indosat yang tergabung dalam wadah Komunitas ISATBB yang berjumlah 2969 orang. Teknik pengambilan sampel yang digunakan pada penelitian ini adalah Simple Random Sampling. Ukuran sampel (sample size) didasarkan rumus Slovin diperoleh sebesar 97 responden. Hasil uji validitas untuk keseluruhan butir pertanyaan yang mewakili 3 variabel (33 butir pertanyaan) menunjukkan hasil keseluruhan yang valid. Disamping itu juga untuk menguji konsistensi jawaban responden dilakukan uji reliabilitas menggunakan teknik Cronbach's Alpha. Hasil uji reliabilitas untuk variabel kualitas layanan, kepuasan pelangan, dan loyalitas nasabah adalah sebagai berikut: 0,$718 ; 0,738$; dan 0,582 (lebih besar dari $r$ tabel 0,17 ).

\section{Tehnik Analisis}

Sebelum data dianalisis dilakukan transformasi data untuk meningkatkan derajat skala pengukuran dan sebagai prasyarat path analysis, yaitu transformasi dari skala ordinal ke interval. Path analysis digunakan untuk menganalisis pola hubungan antar variabel dengan tujuan untuk mengetahui kontribusi atau pengaruh langsung maupun tidak langsung seperangkat variabel bebas (eksogen) terhadap variabel terikat (endogen).

Path analysis yang digunakan pada penelitian ini adalah path analysis model trimming. Menurut (Heise, Al-Rasyid \& Sitepu, Kusnendi) yang dikutip oleh Riduwan dan Kuncoro (2007,p127), model trimming adalah model yang digunakan untuk memperbaiki suatu model struktur analisis jalur dengan cara mengeluarkan dari model variabel eksogen yang koefisien jalurnya tidak signifikan. 


\section{Dasar Teori}

Untuk variabel kualitas pelayanan dasar teori yang digunakan adalah dimensi kualitas layanan menurut Kotler \& Keller (2009, p56), yaitu terdapat lima penentu mutu jasa yang kemudian dikembangkan menjadi 21 item skala SERVQUAL (yang selanjutnya dijadikan indikator). Adapun lima dimensi utama tersebut adalah: Tangible (Berwujud), Reliability (Keandalan), Responsiveness (Tanggapan), Assurance (Jaminan), dan Empathy (Empati). Untuk variabel kepuasan pelanggan menggunakan indikator dengan dasar teori dimensi kepuasan pelanggan yang dikemukakan oleh Irawan (2002, p37-40) yang mengemukakan faktor-faktor pendorong kepuasan konsumen terbagi atas lima bagian yaitu; Kualitas Produk, Harga, Service Quality, Emotional Factor, dan Kemudahan. Dalam mengukur kepuasan pelanggan menggunakan analisis gap dengan mendasarkan pada teori Kotler (2000), Richard F. Gerson (dalam Arief, 2005, p167), Wilkie ( dalam Tjiptono, 2007, p349). Untuk variabel loyalitas pelanggan menggunakan dasar teori yang dikemukakan oleh Griffin (2005, p33-34) yang menyatakan ada empat aspek dalam pengukuran loyalitas; melakukan pembelian berulang secara teratur, membeli antarlini produk dan jasa, merekomendasikan kepada orang lain, dan menunjukkan kekebalan terhadap tarikan pesaing.

Adapun dasar teori tentang hubungan antar tiga variabel (kualitas layanan, kepuasan pelanggan, dan loyalitas pelanggan) adalah seperti yang dikemukakan dalam Aydin dan Oyzer (2005) yang menyatakan bahwa kualitas jasa memiliki pengaruh positif terhadap loyalitas (ningtyastuti, 2009, p23). Bagozzi's (1992) dalam Ningtyastuti (2009) mengungkapkan bahwa "perceived service quality was an appraisal construct; appraisal normally precedes emotional responses such as satisfaction" (Chiou dan Droge, 2006). "several other empirical studies also confirm the perceived service quality > satisfaction ordering, which corresponds to the traditional attitude structure sequence" (Cronin dan Taylor 1992 et al: Chiou dan Droge, (2006). Sementara itu, Oliver (1997) dalam Ningtyastuti (2009) menyatakan bahwa kesetiaan konsumen dalam bentuk pembelian kembali produk dan layanan merupakan hasil dari kepuasan konsumen.

Kepuasan merupakan salah satu indikator dalam meningkatkan loyalitas konsumen. Hal ini menunjukan bahwa, semakin tinggi tingkat kepuasan konsumen maka semakin besar pula loyalitas yang diberikan oleh konsumen. Kepuasan merupakan satu indikator dalam mengingkatkan loyalitas konsumen. Kepuasan memiliki peran penting dalam membentuk loyalitas, terutama loyalitas yang berada pada tahap afektif. Kepuasan yang mendasari terbentuknya loyalitas afektif dapat didasarkan atas kualitas (quality-based), atau atas dasar harga (price-based).

\section{Hasil Analisis}

\section{Analisis Pengaruh Kualitas Layanan Terhadap Kepuasan Pelanggan}

Pada bagian ini akan dijelaskan sub struktur 1, yaitu mengenai analisis jalur antara kualitas layanan $(X)$, terhadap kepuasan pelanggan $(Y)$. Hasil yang diperoleh adalah seperti yang ditunjukkan oleh tabel 1,2, dan 3. Adapun persamaan struktural untuk sub-struktur 1 adalah:

Tabel 1 Anova Sub-Struktur 1

\begin{tabular}{llccccc}
\hline \multicolumn{1}{c}{ Model } & Sum of Squares & Df & Mean Square & F & Sig. \\
\hline 1 & Regression & 6.597 & 1 & 6.597 & 30.098 & $.000^{\mathrm{a}}$ \\
Residual & 21.480 & 98 & .219 & & \\
Total & 28.078 & 99 & & & \\
\hline a. Predictors: (Constant), KualitasLayanan & & & \\
b. Dependent Variable: KepuasanPelanggan \\
Sumber: Hasil Pengolahan Data 2010
\end{tabular}


Tabel 2 Model Summary Sub Struktur 2

\begin{tabular}{|c|c|c|c|c|c|c|c|c|c|}
\hline \multirow[b]{2}{*}{ Model } & \multirow[b]{2}{*}{$\mathrm{R}$} & \multirow[b]{2}{*}{ R Square } & \multirow{2}{*}{$\begin{array}{c}\text { Adjusted R } \\
\text { Square }\end{array}$} & \multirow{2}{*}{$\begin{array}{l}\text { Std. Error of } \\
\text { the Estimate }\end{array}$} & \multicolumn{5}{|c|}{ Change Statistics } \\
\hline & & & & & $\begin{array}{l}\text { R Square } \\
\text { Change }\end{array}$ & F Change & df1 & $\mathrm{df} 2$ & $\begin{array}{l}\text { Sig. F } \\
\text { Change }\end{array}$ \\
\hline 1 & $.485^{\mathrm{a}}$ & .235 & .227 & .46817 & .235 & 30.098 & 1 & 98 & .000 \\
\hline
\end{tabular}

a. Predictors: (Constant), KualitasLayanan

Sumber: Hasil Pengolahan Data 2010

\section{Pengujian Hipotesis}

Hipotesis yang diambil adalah $\mathrm{H}_{\mathrm{o}}$ yakni tidak adanya kontribusi yang signifikan antara variabel Kualitas Layanan terhadap variabel Kepuasan Pelanggan layanan BlackBerry Indosat; dan $\mathrm{H}_{\mathrm{a}}$ yakni adanya kontribusi yang signifikan antara variabel Kualitas Layanan terhadap variabel Kepuasan Pelanggan layanan BlackBerry Indosat.

Sementara itu, keputusan yang didapatkan adalah sebagai berikut. Dari Tabel 2 ANOVA, diperoleh nilai $\mathrm{F}$ sebesar 30,098 dengan nilai probabilitas $(\mathrm{sig})=0,000$. Karena nilai sig $<0,05$, maka keputusannya adalah $\mathrm{H}_{\mathrm{o}}$ ditolak dan $\mathrm{H}_{\mathrm{a}}$ diterima. Besarnya pengaruh variabel kualitas layanan $(X)$ dan kepuasan pelanggan $(Y)$, dapat diketahui dengan melihat nilai $R$ square pada Tabel 2 Model Summary, bahwa $\mathrm{R}^{2}=0,235$ atau $23,5 \%$. Besarnya pengaruh dari variabel lain yang mempengaruhi Kepuasan Pelanggan adalah sebesar $76,5 \%$. Sedangkan besarnya koefisien jalur bagi variabel lain di luar penelitian yang mempengaruhi nilai $\mathrm{Y}$, dapat dihitung melalui rumus sebagai berikut:

$$
\begin{aligned}
& \mathrm{Y}=\rho_{\mathrm{y}} \mathrm{X}+\rho \mathrm{Y} \varepsilon_{1} \\
& \mathrm{R}_{\mathrm{zxy}}^{2}=0,235 \rho_{\mathrm{y}} \varepsilon_{1}=\sqrt{1-\mathrm{R}_{\mathrm{zxy}}^{2}}=\sqrt{1-0,235}=0,874
\end{aligned}
$$

Tabel 3 Coefficients Sub-Struktur 1

\begin{tabular}{llccccc}
\hline \multirow{2}{*}{ Model } & \multicolumn{2}{c}{ Unstandardized Coefficients } & $\begin{array}{c}\text { Standardized } \\
\text { Coefficients }\end{array}$ & t & Sig. \\
\cline { 2 - 5 } & (Constant) & 1.129 & Std. Error & Beta & & \\
\hline 1 & KualitasLayanan & .660 & .413 & & 2.733 & .007 \\
& & .120 & .485 & 5.486 & .000 \\
\hline
\end{tabular}

a. Dependent Variable: KepuasanPelanggan

Sumber: Hasil Pengolahan Data 2010

$$
\begin{aligned}
& \mathrm{Y}=\rho_{\mathrm{yX}}+\rho_{\mathrm{Y}} \varepsilon_{1} \\
& \mathrm{Y}=0,485 \mathrm{X}+0,874 \varepsilon_{1}
\end{aligned}
$$

\section{Analisis Kualitas Layanan (X) serta Kepuasan Pelanggan (Y) terhadap Loyalitas Pelangan (Z) layanan BlackBerry Indosat}

Pada bagian ini akan dijelaskan sub struktur 2, yaitu mengenai analisis jalur antara kualitas layanan (X), kepuasan pelanggan (Y), terhadap loyalitas pelanggan (Z). Hasil yang diperoleh adalah seperti yang ditunjukkan oleh Tabel 4, 5, dan 6. Adapun persamaan struktural untuk sub-struktur 2 adalah: 
Tabel 4 ANOVA Sub-Struktur 2

\begin{tabular}{llccccc}
\hline & Model & Sum of Squares & df & Mean Square & F & Sig. \\
\hline 1 & Regression & 20.369 & 2 & 10.184 & 114.801 & $.000^{\mathrm{a}}$ \\
& Residual & 8.605 & 97 & .089 & & \\
& Total & 28.974 & 99 & & & \\
\hline
\end{tabular}

a. Predictors: (Constant), KepuasanPelanggan, KualitasLayanan

b. Dependent Variable: LoyalitasPelanggan

Sumber: Hasil Pengolahan Data dengan 2010

Tabel 5 Coefficients Sub-Struktur 2

\begin{tabular}{|c|c|c|c|c|c|c|}
\hline & \multirow[t]{2}{*}{ Model } & \multicolumn{2}{|c|}{ Unstandardized Coefficients } & \multirow{2}{*}{$\begin{array}{c}\begin{array}{c}\text { Standardized } \\
\text { Coefficients }\end{array} \\
\text { Beta }\end{array}$} & \multirow[t]{2}{*}{$\mathbf{t}$} & \multirow[t]{2}{*}{ Sig. } \\
\hline & & B & Std. Error & & & \\
\hline \multirow[t]{3}{*}{1} & (Constant) & -.099 & .273 & & -.365 & .716 \\
\hline & KualitasLayanan & .396 & .088 & .286 & 4.526 & .000 \\
\hline & KepuasanPelanggan & .672 & .064 & .661 & 10.455 & .000 \\
\hline
\end{tabular}

a. Dependent Variable: LoyalitasPelanggan

Sumber: Hasil Pengolahan Data dengan 2010

Tabel 6 Model Summary Sub-Struktur 2

\begin{tabular}{|c|c|c|c|c|c|c|c|c|c|}
\hline \multirow[b]{2}{*}{ Model } & \multirow[b]{2}{*}{$\mathbf{R}$} & \multirow[b]{2}{*}{ R Square } & \multirow{2}{*}{$\begin{array}{l}\text { Adjusted R } \\
\text { Square }\end{array}$} & \multirow{2}{*}{$\begin{array}{l}\text { Std. Error of } \\
\text { the Estimate }\end{array}$} & \multicolumn{5}{|c|}{ Change Statistics } \\
\hline & & & & & $\begin{array}{c}\text { R Square } \\
\text { Change }\end{array}$ & F Change & df1 & df2 & Sig. F Change \\
\hline 1 & $.838^{\mathrm{a}}$ & .703 & .697 & .29785 & .703 & 114.801 & 2 & 97 & .000 \\
\hline
\end{tabular}

a. Predictors: (Constant), KepuasanPelanggan, KualitasLayanan

Sumber: Hasil Pengolahan Data dengan 2010

Hipotesis yang diambil adalah $\mathrm{H}_{\mathrm{o}}$ yakni tidak adanya pengaruh antara variabel Kualitas Layanan dan Kepuasan Pelanggan secara simultan dan signifikan terhadap variabel Loyalitas Pelanggan layanan BlackBerry Indosat; dan $\mathrm{H}_{\mathrm{a}}$ yakni adanya pengaruh atau kontribusi antara variabel Kualitas Layanan dan Kepuasan Pelanggan secara simultan dan signifikan terhadap variabel Loyalitas Pelanggan layanan BlackBerry Indosat.

Sementara itu, keputusan yang diperoleh adalah sebagai berikut. Dari Tabel 5 ANOVA diperoleh nilai $\mathrm{F}$ sebesar 114,801 dengan nilai probabilitas (sig) $=0,000$. Karena nilai $\operatorname{sig}<0,05$, maka keputusannya adalah $\mathrm{H}_{\mathrm{o}}$ ditolak dan $\mathrm{H}_{\mathrm{a}}$ diterima. Oleh sebab itu, pengujian secara individual dapat dilakukan.

Besarnya kontribusi variabel Kualitas Layanan dan Kepuasan Pelanggan secara simultan terhadap variabel Loyalitas Pelanggan dapat diketahui dengan melihat nilai $R^{2}$ pada Tabel 5 sebesar = 0,703 atau $70,3 \%$. Besarnya pengaruh dari variabel lain yang berkontribusi terhadap Loyalitas Pelanggan di luar penelitian ini adalah sebesar $29,7 \%$. Sementara itu, besarnya koefisien jalur bagi variabel lain di luar penelitian yang mempengaruhi nilai dapat dihitung melalui rumus sebagai berikut:

$\mathrm{R}_{\mathrm{zxy}}^{2}=0,703 \rho_{\mathrm{Y}} \varepsilon_{2}=\sqrt{1-\mathrm{R}_{\mathrm{zxy}}^{2}}=\sqrt{1-0,703}=0,544$ 


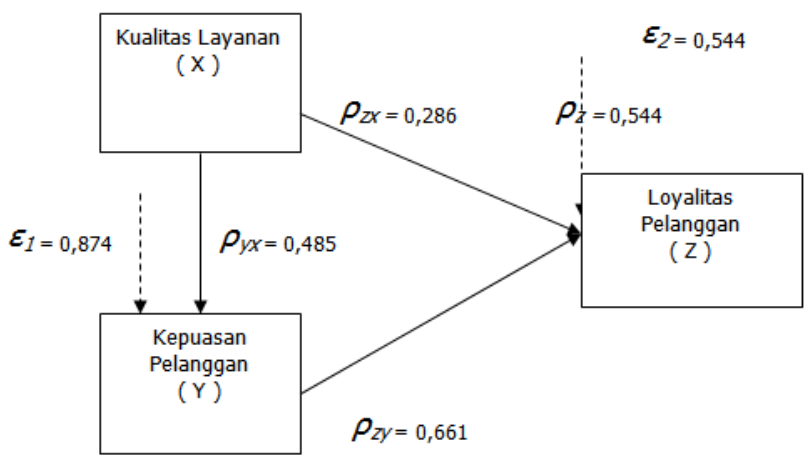

Gambar 1 Struktur Hubungan X, Y dan Z beserta Koefisien Jalur Sumber: Hasil Pengolahan Data

Dari Gambar 1 tersebut, diketahui bahwa seluruh koefisien jalur dari hubungan, maka diketahui pula kontribusi langsung, tidak langsung serta kontribusi total dari tiap-tiap variabel yang mempengaruhi variabel tertentu. Hasilnya dirangkum dalam tabel di bawah ini.

Tabel 7 Koefisien Jalur, Pengaruh Langsung, Pengaruh Tidak Langsung, Pengaruh Total dan Pengaruh Kualitas Layanan $(X)$,

Kepuasan Pelanggan $(Y)$ secara Simultan dan Signifikan terhadap Loyalitas Pelanggan $(Z)$

\begin{tabular}{ccccc}
\hline & & \multicolumn{3}{c}{ Pengaruh } \\
\cline { 3 - 5 } Variabel & Koefisien Jalur & Langsung & $\begin{array}{c}\text { Tidak Langsung } \\
\text { (Melalui } \mathbf{Y} \text { ) }\end{array}$ & Total \\
\hline$X$ terhadap $Y$ & 0,485 & 0,485 & - & 0,485 \\
& & & & \\
$X$ terhadap $Z$ & 0,286 & 0,286 & $0,485 \times 0,661=0,3205$ & \\
$Y$ terhadap $Z$ & 0,661 & 0,661 & - & 0,661 \\
\hline
\end{tabular}

Sumber: Hasil Pengolahan Data 2010

Jadi, hasil keseluruhan kontribusi variabel Kualitas Layanan (X) terhadap Kepuasan Pelanggan (Y) serta dampaknya terhadap Loyalitas Pelanggan (Z) adalah sebagai berikut. Penerapan Kualitas Layanan $(X)$ terhadap Kepuasan Pelanggan $(Y)$ layanan BlackBerry Indosat sebesar $(0,485)^{2}=$ $23,52 \%$, sisanya sebesar $76,48 \%$ nilai dipengaruhi oleh variabel lainnya di luar penelitian ini. Penerapan Kualitas Layanan (X) secara langsung berkontribusi terhadap Loyalitas Pelanggan $(Z)$ layanan BlackBerry Indosat sebesar $(0,286)^{2}=8,17 \%$. Sisanya sebesar $91,83 \%$ nilai variabel sikap konsumen dipengaruhi oleh variabel lainnya di luar penelitian ini. Penerapan Kualitas Layanan $(X)$ berkontribusi secara tidak langsung terhadap Loyalitas Pelanggan $(Z)$ layanan BlackBerry Indosat sebesar $(0,6065)^{2}=36,78 \%$. Sisanya sebesar $63,22 \%$ nilai variabel Loyalitas Pelanggan dipengaruhi oleh variabel lainnya di luar penelitian ini. Penerapan Kepuasan Pelanggan $(Y)$ memberikan kontribusi terhadap Loyalitas Pelanggan $(Z)$ sebesar $(0,661)^{2}=43,69 \%$. Sisanya sebesar $56.31 \%$ nilai variabel Loyalitas Pelanggan dipengaruhi oleh variabel lainnya di luar penelitian ini.

\section{Implikasi Hasil Penelitian}

Berdasarkan hasil penelitian, berikut ini akan dikemukakan beberapa implikasi yang dianggap relevan dengan penelitian. Implikasi tersebut antara lain sebagai berikut. Hasil pengolahan dan analisis data menunjukkan bahwa Kualitas Layanan $(X)$ memberikan kontribusi yang signifikan terhadap 
Kepuasan Pelanggan $(Y)$ sebesar 23,52\%. Kontribusi ini cukup besar, namun diperlukan upaya-upaya untuk meningkatkan Kualitas Layanan BlackBerry Indosat yang dapat mempengaruhi Kepuasan Pelanggan layanan BlackBerry Indosat sehingga akan menambah jumlah pelanggan. Hasil pengolahan dan analisis data menunjukkan Kualitas Layanan $(X)$ memberikan kontribusi secara langsung yang signifikan terhadap Loyalitas Pelanggan $(Z)$ sebesar 8,17\%. Kontribusi ini dirasa kecil, untuk itu diperlukan upaya-upaya untuk lebih meningkatkan Loyalitas Pelanggan layanan BlackBerry Indosat dengan cara memperbaiki Kualitas Layanan BlackBerry Indosat serta penanganan keluhan pelanggan dengan tepat dan cepat.

Hasil pengolahan dan analisis data menunjukkan bahwa Kualitas Layanan $(X)$ memberikan kontribusi secara tidak langsung yang signifikan terhadap Loyalitas Pelanggan (Z) sebesar 36,78\%, yaitu kontribusi yang melalui Kepuasan Pelanggan $(Y)$. Jadi, perusahaan harus dapat memperbaiki Kualitas Layanan yang akan meningkatkan Kepuasan Pelanggan dan selanjutnya akan berkontribusi terhadap Loyalitas Pelanggan layanan BlackBerry Indosat. Hasil pengolahan dan analisis data menunjukkan bahwa Kepuasan Pelanggan $(Y)$ memberikan kontribusi yang signifikan terhadap Loyalitas Pelanggan $(Z)$ sebesar 43,69\%. Kontribusi ini sangat besar, jadi seharusnya perusahaan meningkatkan Kepuasan Pelanggan agar Loyalitas Pelanggan layanan BlackBerry Indosat semakin meningkat.

\section{SIMPULAN}

Dari pembahasan yang telah dipaparkan, maka dapat ditarik beberapa simpulan sebagai berikut (1) Kualitas layanan berkontribusi secara signifikan terhadap Kepuasan Pelanggan, (2) Kualitas Layanan berkontribusi secara signifikan terhadap Loyalitas Pelanggan, Kualitas Layanan dan Kepuasan berkontribusi secara signifikan dan secara simultan terhadap Loyalitas Pelanggan layanan BlackBerry Indosat.

Adapun saran yang dapat diberikan kepada PT Indosat, tbk adalah sebagai berikut. Untuk variabel Kualitas Layanan, sebaiknya BlackBerry Indosat mengadakan perbaikan seperti memberikan arahan kepada customer service galeri Indosat agar bersikap lebih ramah dan sopan terhadap pelanggan dan mempunyai rasa ingin membantu pelanggan yang besar. Untuk variabel kepuasan pelanggan, sebaiknya BlackBerry Indosat mengadakan perbaikan seperti penanganan keluhan yang cepat dan tepat sesuai dengan keinginanan pelanggan agar mereka merasa lebih puas, dan memperbaharui sistem pembayaran layanan BlackBerry Indosat agar lebih mudah dan nyaman bagi pelanggan. Untuk variabel loyalitas pelanggan, sebaiknya BlackBerry Indosat meningkatkan kualitas layanannya serta diimbangi dengan meningkatnya kepuasan pelanggan karena kedua hal ini merupakan cara yang sangat berpengaruh untuk meningkatkan loyalitas pelanggan secara signifikan.

\section{DAFTAR PUSTAKA}

Arief. (2007). Pemasaran jasa dan kualitas pelayanan - bagaimana mengelola kualitas pelayanan agar memuaskan pelanggan, edisi pertama, Malang: PT Bayumedia Publishing.

Chiou J. dan Droge, Cornelia. (2006). "Trust, specific asset, investment, and expertise: direct and indirect effects in a satisfaction - loyalty framework." Journal of the Academy of Marketing Science, Vol. 8. (5), P.34.

Cronin, J.J. dan Steven A.Taylor (1992). Measuring service quality: a reexamination and extension, The Journal of Marketing Vol. 56 No. 3 P 55-68. 
Griffin, J. (2005). Customer loyalty: Menumbuhkan dan mempertahankan kesetiaan pelanggan, Jakarta: Penerbit Erlangga.

Irawan, H. (2002). Sepuluh prinsip kepuasan pelanggan, Jakarta: Gramedia.

Kotler, P., dan Keller, K.L. (2009). Manajemen pemasaran, jilid pertama, edisi keduabelas, PT Indeks, Kelompok Gramedia: Jakarta.

Ningtyastuti, R. (2009). Pengaruh kualitas jasa, kepuasan dan kepercayaan terhadap kesetiaan, Depok: FISIP UI.

Riduwan dan Kuncoro, E.A. (2007). Cara menggunakan dan memakai analisis jalur (path analysis), Bandung: Penerbit Alfabeta.

Tjiptono, F. (2000). Strategi pemasaran, edisi kedua, Yogyakarta: Penerbit Andi. 